\title{
Health-related outcomes and economic burden in Japan: focus on inflammatory bowel disease, multiple sclerosis, and depression
}

This article was published in the following Dove Press journal:

ClinicoEconomics and Outcomes Research

\author{
Kaoru Yamabe \\ Healthcare Policy and Access, Takeda \\ Pharmaceutical Company Limited, \\ Chuou-ku, Tokyo, Japan
}

This series presents articles using data collected from the National Health and Wellness Survey ${ }^{1}$ in Japan to assess the burden of inflammatory bowel disease (IBD), multiple sclerosis (MS), and depression using a common methodology involving cases vs controls and patient-reported outcome measures (PROMs). This series covers a breadth of comorbidity types, from gastrointestinal (IBD) to neurological (MS) to mental health (depression) domains, thus allowing the reader to appreciate the extent of each of these burdens both individually and in the broader context of other disease areas. Moreover, it helps shed light on these burdens across a variety of outcomes (including healthrelated quality of life, productivity impairment, resource utilization, and monetary costs attributed to work impairment and resource utilization), thus contributing to the limited current data published on Japanese patients' burden due to these conditions. The database is a population-based, self-reported online survey recruiting respondents from opt-in online panels. The survey collects demographic information, health characteristics, and PROMs across respondents with a wide range of disease conditions.

While the three articles employ a common data source and share PROMs, there are some differences of note. The MS article, for example, assesses the burden of MS in Japan in relation to the broader context of the corresponding burdens in the United States and in five countries of the European Union (France, Germany, Italy, Spain, and the United Kingdom). The depression article looks not only at the burden of diagnosed depression, but also at undiagnosed depression, which helps reveal a "hidden burden" that can be more readily identified via PROMs than via other data collection methods.

In summary, this thematic series presents three patient-reported outcome studies evaluating burden of illness in Japan within distinct conditions, thus helping assess unmet needs for improved patient care and treatment.

\section{Disclosure}

Kaoru Yamabe is an employee of Takeda Pharmaceutical Company Limited, which funded this research. The author reports no other conflict of interest in this work.

\section{Reference}

1. Kantar Health. National Health and Wellness Survey. Patient-Reported Healthcare Insights. New York: Kantar Health. Available from: http://www.kantarhealth.com/docs/datasheets/kh-national-health-andwellness-survey.pdf. Accessed July 25, 2018. 
Dove Medical Press encourages responsible, free and frank academic debate. The content of the ClinicoEconomics and Outcomes Research 'Editorial' section does not necessarily represent the views of Dove Medical Press, its officers, agents, employees, related entities or the ClinicoEconomics and Outcomes Research editors. While all reasonable steps have been taken to confirm the content of each Editorial, Dove Medical Press accepts no liability in respect of the content of any Editorial, nor is it responsible for the content and accuracy of any Editorial.

\section{Publish your work in this journal}

ClinicoEconomics and Outcomes Research is an international, peerreviewed open-access journal focusing on health technology assessment, pharmacoeconomics and outcomes research in the areas of diagnosis, medical devices, and clinical, surgical and pharmacological intervention. The economic impact of health policy and health systems organization also constitute important areas of coverage. The manuscript management system is completely online and includes a very quick and fair peer-review system, which is all easy to use. Visit http://www.dovepress.com/testimonials.php to read real quotes from published authors.

Submit your manuscript here: https://www.dovepress.com/clinicoeconomics-and-outcomes-research-journal 